National and Global Petroleum Assessment

\title{
Assessment of Undiscovered Gas Resources of the Sacramento Basin Province in California, 2019
}

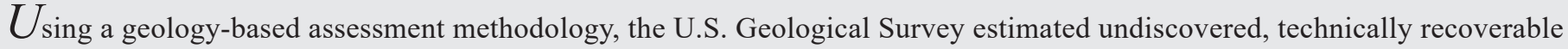
mean resources of 512 billion cubic feet of gas in the Upper Jurassic-Neogene Total Petroleum System of the Sacramento Basin Province in California.

\section{Introduction}

The U.S. Geological Survey (USGS) quantitatively assessed the potential for undiscovered, technically recoverable gas resources in the Upper Jurassic-Neogene Total Petroleum System (TPS) of the Sacramento Basin Province in California (fig. 1). The Sacramento Basin and the San Joaquin Basin Provinces occupy the Great Valley of California, a remnant forearc basin that was situated between the Sierran-Klamath magmatic arc and the Franciscan accretionary complex (Ingersoll, 1979; Orme and Surpless, 2019). The Sacramento Basin and San Joaquin Basin are separated by the Stockton Arch.

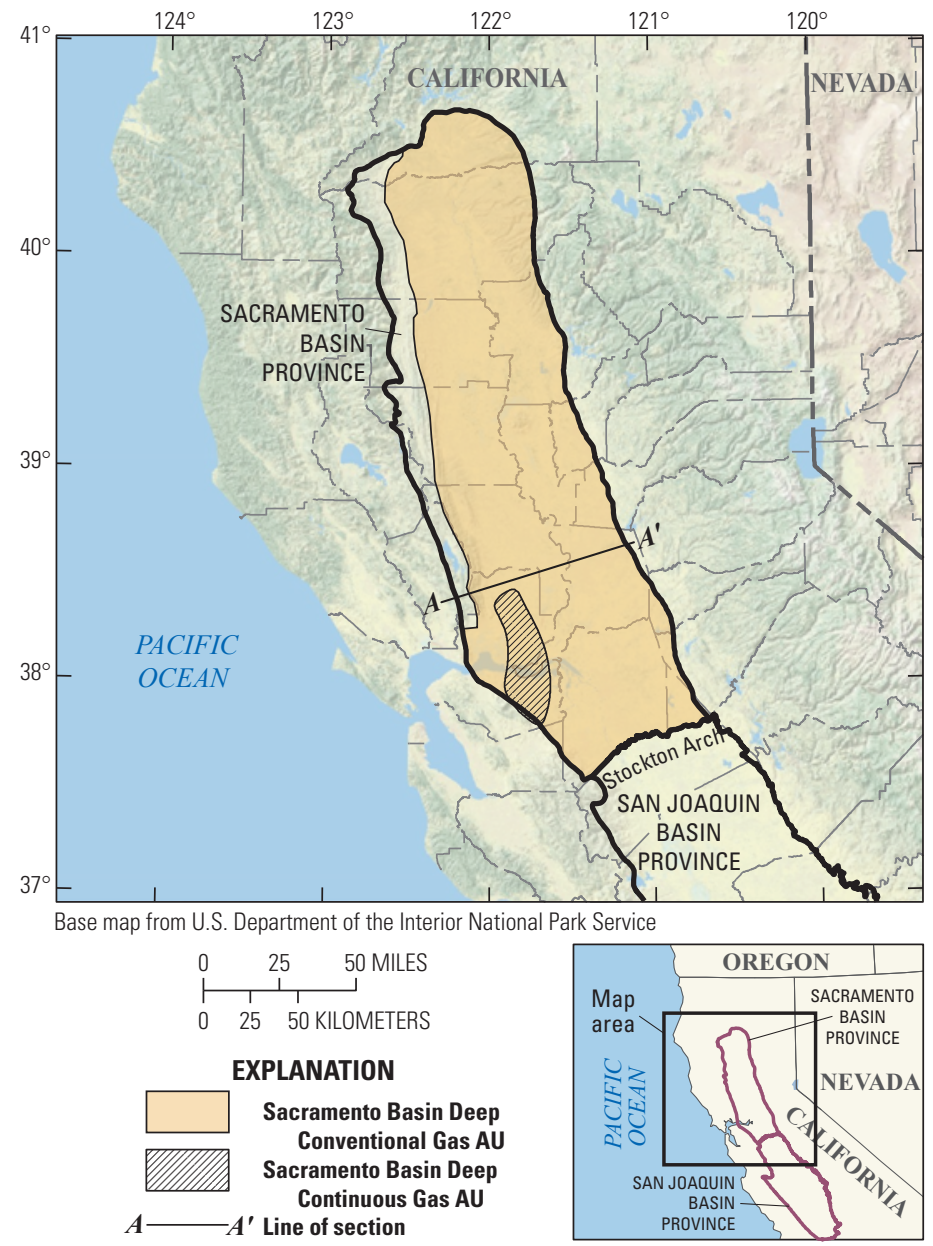

Figure 1. Map showing the location of two assessment units (AUs) of the Sacramento Basin Province in California.
More than 120 gas fields have been discovered in sandstone reservoirs from the Upper Cretaceous through the Tertiary. Reservoirs range from deltaic sandstones to deep-water slope-channel and basin-floor sandstones (Moore and Nilsen, 1990; Nilsen, 1990; Williams and Graham, 2013). Exploration for gas is at an extremely mature stage within the Upper Cretaceous Dobbins Shale (following the nomenclature of Edmonson, 1962) and younger stratigraphic units (Hosford Scheirer and others, 2007).

This assessment explores the possibility that there are potential undiscovered gas resources in Upper Jurassic and Cretaceous (prior to the formation of the Dobbins Shale) reservoirs in the western part of the Sacramento Basin Province, as few wells have been tested in this part of the stratigraphic section (Graham, 1981; Williams and others, 1998). The existence of Upper Jurassic rocks in the Sacramento Basin is uncertain (Surpless and others, 2006; Orme and Surpless, 2019). The concept is not new that older rocks along the western margin of the basin might host potential hydrocarbon accumulations (Graham, 1981; Jenden and Kaplan, 1989) because organic-rich marine shales deposited in anoxic water in the deep basin have been proposed in the past. Oil seeps along the western margin of the basin spurred exploration and geologic field studies as early as the late 1800s (fig. 2) (Watts, 1894; Trask and Hammar, 1934). The discovery of gas in Upper Cretaceous and Tertiary rocks in the 1930s shifted the emphasis of exploration to the shallower stratigraphic section throughout the basin.

In this study, the hypothesis is that marine shales within parts of the Upper Jurassic-Lower Cretaceous Stony Creek Formation (fig. 3) (Graham, 1981; Bertucci, 1983); Lower Cretaceous Lodoga Formation; and Upper Cretaceous Boxer, Venado, Yolo, Sites, Funks, and Guinda Formations may have been source rocks for oil and gas. In this hypothesis, oil that was generated would have mostly cracked to gas during maximum subsidence and burial in the Cretaceous (Moxon and Graham, 1987), and gas might remain reservoired in sandstones within deep structural traps or within low-permeability sandstones. Thermogenic gas that was ultimately derived from marine shales may have migrated into the shallower, thermally immature part of the section before mixing with gases from several other sources (Jenden and Kaplan, 1989).

\section{Total Petroleum System and Assessment Units}

The USGS defined the Upper Jurassic-Neogene TPS to encompass gases with mixed compositions from several sources throughout the Sacramento Basin Province (Jenden and Kaplan, 1989). The Sacramento Basin Deep Conventional Gas Assessment Unit (AU) was defined to include thermogenic gas and other gases within conventional reservoirs underlying the Dobbins Shale in deep structural traps (Sterling, 2018). The Sacramento Basin Deep Conventional Gas AU also includes the 
possibility for small gas accumulations in the Upper Cretaceous-Tertiary stratigraphic section, as these reservoirs were the focus of previous assessments (Beyer, 1988; Hosford Scheirer and others, 2007). The Sacramento Basin Deep Continuous Gas AU was defined to include the potential for thermogenic gas that may have migrated locally into low-permeability (tight) sandstones in the deep central part of the basin. Both AUs were assigned geologic risk associated with adequate hydrocarbon charge, and the Sacramento Basin Deep Conventional Gas AU was also assigned risk on the presence of adequate reservoir porosity and permeability.

The geologic model underlying the assessment of the Sacramento Basin Deep Conventional Gas AU is for oil and gas to have been generated within organic-rich Upper Jurassic-Lower Cretaceous marine shales. At present, the thermal window for oil generation begins at a depth of about 10,000 feet, as the Sacramento Basin throughout its history has had a low thermal gradient (Dumitru, 1988; Jenden and Kaplan, 1989). Oil may have cracked to gas with deep burial, and some gas may have migrated into deep-marine sandstone reservoirs within structural traps (Garcia, 1981; Cherven, 1983). The geologic model relies on some volume of gas being ultimately sourced from Type II marine kerogen rather than relying solely on Type III kerogen (Zieglar and Spotts, 1978). Numerous oil seeps along the western margin of the basin provide some evidence of oil generation (Graham, 1981; Jenden and Kaplan, 1989). The geologic model for the Sacramento Basin Deep Continuous Gas AU is for thermogenic gas to have migrated locally into low-permeability, deep-marine sandstones. Overpressure is present throughout much of the basin and is commonly ascribed to hydrocarbon generation, but overpressure in the Sacramento Basin may have a tectonic cause (McPherson and Garven, 1999).

Key assessment input data are shown in table 1.
Table 1. Key input data for two assessment units of the Sacramento Basin Province in California.

[Well drainage area and success ratios are defined partly using U.S. shale-gas analogs. The average EUR input is the minimum, median, maximum, and calculated mean. Shading indicates not applicable. AU, assessment unit; \%, percent; EUR, estimated ultimate recovery (per well); BCFG, billion cubic feet of gas]

\begin{tabular}{|c|c|c|c|c|}
\hline \multirow{2}{*}{$\begin{array}{c}\text { Assessment input } \\
\text { data- } \\
\text { Conventional AU }\end{array}$} & \multicolumn{4}{|c|}{ Sacramento Basin Deep Conventional Gas AU } \\
\hline & $\begin{array}{l}\text { Mini- } \\
\text { mum }\end{array}$ & Median & $\begin{array}{l}\text { Maxi- } \\
\text { mum }\end{array}$ & $\begin{array}{c}\text { Calculated } \\
\text { mean }\end{array}$ \\
\hline Number of gas fields & 1 & 12 & 48 & 13.2 \\
\hline Size of gas fields & 3 & 6 & 1,500 & 22.5 \\
\hline AU probability & 0.63 & & & \\
\hline \multirow{2}{*}{$\begin{array}{c}\text { Assessment input } \\
\text { data- } \\
\text { Continuous AU }\end{array}$} & \multicolumn{4}{|c|}{ Sacramento Basin Deep Continuous Gas AU } \\
\hline & $\begin{array}{l}\text { Mini- } \\
\text { mum }\end{array}$ & Mode & $\begin{array}{l}\text { Maxi- } \\
\text { mum }\end{array}$ & $\begin{array}{l}\text { Calculated } \\
\text { mean }\end{array}$ \\
\hline $\begin{array}{l}\text { Potential production } \\
\text { area of AU (acres) }\end{array}$ & 320 & 156,000 & 313,000 & 156,440 \\
\hline $\begin{array}{l}\text { Average drainage area of } \\
\text { wells (acres) }\end{array}$ & 40 & 80 & 120 & 80 \\
\hline Success ratio $(\%)$ & 10 & 50 & 90 & 50 \\
\hline Untested area in $\mathrm{AU}(\%)$ & 100 & 100 & 100 & 100 \\
\hline Average EUR (BCFG) & 0.1 & 0.5 & 1.5 & 0.550 \\
\hline AU probability & 0.6 & & & \\
\hline
\end{tabular}

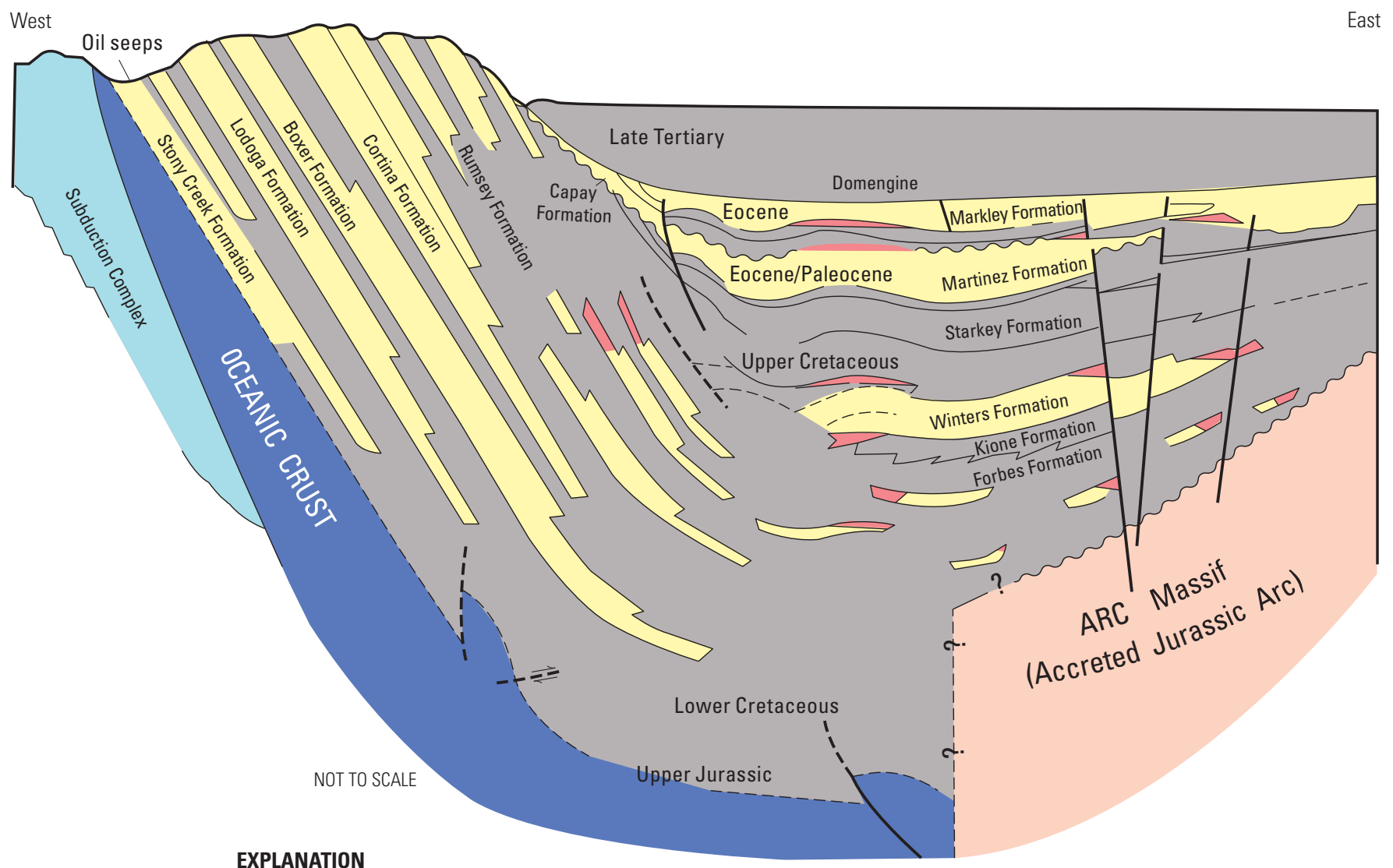

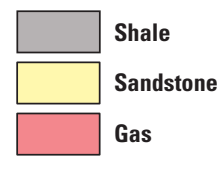

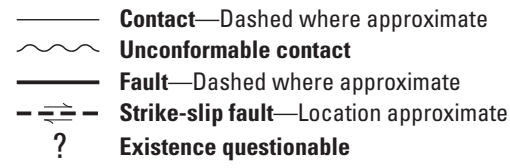

Figure 2. Generalized cross section showing the relationship between the Jurassic and Lower Cretaceous rocks and younger rocks in the Sacramento Basin Province (modified from Dickinson and Seely, 1979). 


\section{Undiscovered Resources Summary}

The USGS quantitatively assessed undiscovered conventional and continuous gas resources within the Upper Jurassic-Neogene TPS of the Sacramento Basin Province in California (table 2). The fully risked, estimated mean total for the Sacramento Basin Province is
512 billion cubic feet of gas (BCFG) with an F95-F5 range from 0 to 1,794 BCFG. Of the estimated mean total of 512 BCFG, 188 BCFG are conventional gas resources with an F95-F5 range from 0 to $717 \mathrm{BCFG}$, and 324 BCFG are continuous gas resources with an F95-F5 range from 0 to 1,077 BCFG. The zeros at the F95 fractiles reflect geologic risk on elements of the TPS.

Table 2. Results for two assessment units of the Sacramento Basin Province in California.

[Results shown are fully risked estimates. F95 represents a 95-percent chance of at least the amount tabulated; other fractiles are defined similarly. Shading indicates not applicable. BCFG, billion cubic feet of gas; NGL, natural gas liquids; MMBNGL, million barrels of natural gas liquids]

\begin{tabular}{|c|c|c|c|c|c|c|c|c|c|c|}
\hline \multirow{3}{*}{$\begin{array}{l}\text { Total petroleum system and } \\
\text { assessment units (AUs) }\end{array}$} & \multirow{3}{*}{$\begin{array}{c}\text { AU } \\
\text { proba- } \\
\text { bility }\end{array}$} & \multirow{3}{*}{$\begin{array}{c}\text { Accum- } \\
\text { ulation } \\
\text { type }\end{array}$} & \multicolumn{8}{|c|}{ Total undiscovered resources } \\
\hline & & & \multicolumn{4}{|c|}{ Gas (BCFG) } & \multicolumn{4}{|c|}{ NGL (MMBNGL) } \\
\hline & & & F95 & F50 & F5 & Mean & F95 & $\mathrm{F50}$ & $\mathbf{F 5}$ & Mean \\
\hline \multicolumn{11}{|c|}{ Upper Jurassic-Neogene Total Petroleum System } \\
\hline $\begin{array}{l}\text { Sacramento Basin Deep } \\
\text { Conventional Gas AU }\end{array}$ & 0.63 & Gas & 0 & 101 & 717 & 188 & 0 & 0 & 0 & 0 \\
\hline $\begin{array}{l}\text { Total undiscovered conventional } \\
\text { resources }\end{array}$ & & & $\mathbf{0}$ & 101 & 717 & 188 & 0 & $\mathbf{0}$ & $\mathbf{0}$ & $\mathbf{0}$ \\
\hline $\begin{array}{l}\text { Sacramento Basin Deep } \\
\text { Continuous Gas AU }\end{array}$ & 0.6 & Gas & 0 & 217 & 1,077 & 324 & 0 & 0 & 1 & 0 \\
\hline $\begin{array}{l}\text { Total undiscovered continuous } \\
\text { resources }\end{array}$ & & & 0 & 217 & 1,077 & 324 & 0 & 0 & 1 & $\mathbf{0}$ \\
\hline Total undiscovered resources & & & 0 & 318 & 1,794 & 512 & 0 & 0 & 1 & 0 \\
\hline
\end{tabular}

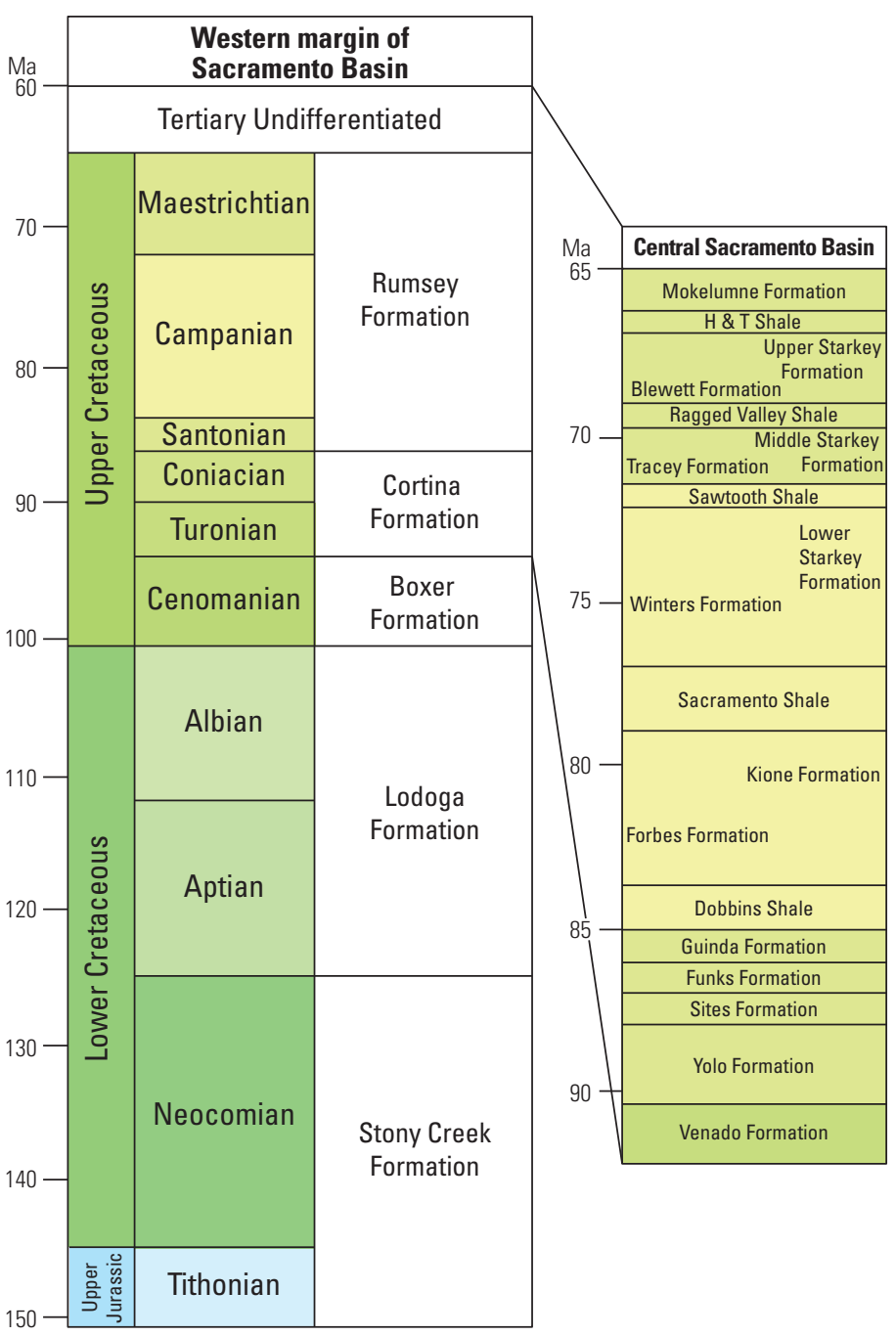

Figure 3. Stratigraphic column for the Sacramento Basin Province, California (modified from Moore and Nilsen, 1990; Nilsen, 1990; Ghosh and Lowe, 1993; Williams and Graham, 2013).

\section{References Cited}

Bertucci, P.F., 1983, Petrology and provenance of the Stony Creek Formation, northwestern Sacramento Valley, California, in Bertucci, P.F., and Ingersoll, R.V., eds., Guidebook to the Stony Creek Formation, Great Valley Group: Sacramento Valley, California, Society of Economic Paleontologists and Mineralogists, Pacific Section, p. 1-16.

Beyer, L.A., 1988, Summary of geology and petroleum plays used to assess undiscovered recoverable petroleum resources of Sacramento Basin Province, California: U.S. Geological Survey Open-File Report 88-450-O, 64 p.

Cherven, V.B., 1983, A delta-slope-submarine fan model for the Maestrichtian part of the Great Valley sequence, Sacramento and San Joaquin Basins, California: American Association of Petroleum Geologists Bulletin, v. 67, no. 5, p. 772-816.

Dickinson, W.R., and Seely, D.R., 1979, Structure and stratigraphy of forearc regions: American Association of Petroleum Geologists Bulletin, v. 63, no. 1, p. 2-31.

Dumitru, T.A., 1988, Subnormal geothermal gradients in the Great Valley forearc basin, California, during Franciscan subduction-A fission track study: Tectonics, v. 7, no. 6, p. 1201-1221.

Edmonson, W.F., 1962, Stratigraphy of the late Upper Cretaceous in the Sacramento Valley: San Joaquin Geological Society, Selected Papers, v. 1, p. 17-26.

Garcia, R., 1981, Depositional systems and their relation to gas accumulation in Sacramento Valley, California: American Association of Petroleum Geologists Bulletin, v. 65 , p. 653-673. 
Ghosh, B., and Lowe, D.R., 1993, The architecture of deepwater channel complexes, Cretaceous Venado Sandstone Member, Sacramento Valley, California, in Graham, S.A., and Lowe, D.R., eds., Advances in the sedimentology of the Great Valley Group: Sacramento Valley, California, Society of Economic Paleontologists and Mineralogists, Pacific Section, p. 51-65.

Graham, S.A., 1981, Stratigraphic and depositional patterns and hydrocarbon occurrence, Sacramento Valley, California, in Graham, S.A., ed., Field guide to the Mesozoic-Cenozoic convergent margin of northern California: American Association of Petroleum Geologists, Pacific Section, v. 50, p. $42-58$.

Hosford Scheirer, A., Tennyson, M.E., Magoon, L.B., Charpentier, R.R., Cook, T.A., Klett, T.R., Pollastro, R.M., and Schenk, C.J., 2007, Assessment of undiscovered natural gas resources of the Sacramento Basin Province of California, 2006: U.S. Geological Survey Fact Sheet 2007-3014, 2 p.

Ingersoll, R.V., 1979, Evolution of the Late Cretaceous forearc basin, northern and central California: Geological Society of America Bulletin, v. 90, no. 9, p. 813-826.

Jenden, P.D., and Kaplan, I.R., 1989, Origin of natural gas in Sacramento Basin, California: American Association of Petroleum Geologists Bulletin, v. 73, no. 4, p. 431-453.

McPherson, B.J.O.L., and Garven, G., 1999, Hydrodynamics and overpressure mechanisms in the Sacramento Basin, California: American Journal of Science, v. 299, no. 6, p. 429-466.

Moore, D.W., and Nilsen, T.H., 1990, Upper Campanian and lower Maestrichtian depositional systems and gas production, southern Sacramento Basin, California, in Ingersoll, R.V., and Nilsen, T.H., eds., Sacramento Valley symposium and guidebook: Society of Economic Paleontologists and Mineralogists, Pacific Section, v. 65, p. 133-142.

Moxon, I.W., and Graham, S.A., 1987, History and controls of subsidence in the Late Cretaceous-Tertiary Great Valley forearc basin, California: Geology, v. 15, no. 7, p. 626-629.

Nilsen, T.H., 1990, Santonian, Campanian, and Maestrichtian depositional systems, Sacramento Basin, California, in Ingersoll, R.V., and Nilsen, T.H., eds., Sacramento
Valley symposium and guidebook: Society of Economic Paleontologists and Mineraologists, Pacific Section, v. 65, p. 95-132.

Orme, D.A., and Surpless, K.D., 2019, The birth of a forearcThe basal Great Valley Group, California, USA: Geology, v. 47, no. 8, p. 757-761.

Sterling, R., 2018, What is next for the "mature" Sacramento Basin? The west side story, a brief look into the Lower Cretaceous and Upper Jurassic rock: American Association of Petroleum Geologists, Search and Discovery Article No. 11091, 51 p., accessed August 23, 2019, at http://www. searchanddiscovery.com/pdfz/documents/2018/11091sterling/ ndx_sterling.pdf.html?q=\%252BauthorStrip $\% 253$ Asterling+isMeetingAbstract $\% 253$ Amtgabsyes.

Surpless, K.D., Graham, S.A., Covault, J.A., and Wooden, J.L., 2006, Does the Great Valley Group contain Jurassic strata? Reevaluation of the age and early evolution of a classic forearc basin: Geology, v. 34, no. 1, p. 21-24.

Trask, P.D., and Hammar, H.E., 1934, Preliminary study of source beds in late Mesozoic rocks on west side of Sacramento Valley, California: American Association of Petroleum Geologists Bulletin, v. 18, no. 10, p. 1346-1373.

Watts, W.L., 1894, Gas and petroleum yielding formations of the Central Valley of California: California State Mining Bureau, Bulletin No. 3, 100 p., accessed August 26, 2019, at https:// babel.hathitrust.org/cgi/pt?id=uc1.31210000023927\&view= 1 up\&seq $=13$.

Williams, T.A., and Graham, S.A., 2013, Controls on forearc basin architecture from seismic and sequence stratigraphy of the Upper Cretaceous Great Valley Group, central Sacramento Basin, California: International Geology Review, v. 55, no. 16, p. 2030-2059.

Williams, T.A., Graham, S.A., and Constenius, K.N., 1998, Recognition of a Santonian submarine canyon, Great Valley Group, Sacramento Basin, California-Implications for petroleum exploration and sequence stratigraphy of deepmarine strata: American Association of Petroleum Geologists Bulletin, v. 82, no. 8, p. 1575-1595.

Zieglar, D.L., and Spotts, J.H., 1978, Reservoir and source-bed history of Great Valley, California: American Association of Petroleum Geologists Bulletin, v. 62, no. 5, p. 813-826.

\section{For More Information}

Assessment results are also available at the USGS Energy Resources Program website at https://energy.usgs.gov.

\section{Sacramento Basin Province Assessment Team}

Christopher J. Schenk, Tracey J. Mercier, Marilyn E. Tennyson, Cheryl A. Woodall, Kristen R. Marra, Heidi M. Leathers-Miller, and Phuong A. Le 